\title{
Flotation of kaolinite from tailings of kaolin-washing plants by cationic collectors
}

\author{
Kianoush Barani ${ }^{1 a}$ \\ ${ }^{1}$ Department of Mining Engineering, Lorestan University, Khorramabad, Iran
}

\begin{abstract}
Traditional processing of kaolin is achieved by dispersion of the mined ore and classification by means of multistage hydrocyclones. The inefficiencies inherent to cyclones produce a middling product that is commonly disposed back to the quarry. In this research recovery of kaolinite from tailings of the Zonoupz kaolin washing plant, which is located in Iran, was investigated by cationic flotation. Flotation experiments showed that flotation of kaolinite from tailings was much better in an acidic than in an alkaline medium containing cationic collectors.
\end{abstract}

\section{Introduction}

In general, kaolin is upgraded by physical methods such as either water-washing or froth flotation. Kaolin particles are predominantly below $25 \mu \mathrm{m}$ and are flat shaped particles. Industrial separation is commonly achieved by dispersion of the mined ore and classification using multistage hydrocyclones. Kaolin reports to overflow, which is then reprocessed in other smaller cyclones. Due to inefficiencies associated with hydrocycloning, most plants are not able to produce clean kaolinite products and after either the $4^{\text {th }}$ or $5^{\text {th }}$ hydrocyclone stage the underflow cannot be further separated further. The underflow is either disposed as waste, sold cheaply to the cement industry and brick-manufacturing or used as back fill in the quarry [1-5].

The Zonouz mine, which is located in eastern Azerbaijan Province, has the only kaolin-washing plant in Iran. The plant has a considerable amount of tailings containing about $15 \% \mathrm{Al}_{2} \mathrm{O}_{3}$. Mineralogically, the tailings consist of quartz, kaolin and iron oxide. The tailing has fine particles ( $100 \%$ finer than $100 \mu \mathrm{m}$ and about $30 \%$ finer than $20 \mu \mathrm{m}$ ), which can be easily dispersed by wind and settled down by rain and snow. Without either treatment or recycling, the tailing would cause environmental pollution. It is important to re-evaluate the tailings because of economic and environmental causes. Evaluation is economically feasible since it does not require additional mining costs. Kaolinite can be retrieved from the tailings by using flotation. However, flotation of kaolinite from the tailing is difficult because kaolinite and quartz, the two main minerals occurring in the tailings, have the same flotation behavior.

Both minerals are negatively charged in a wide range of $\mathrm{pH}$, and therefore they can be floated by amine collectors in acidic and alkaline medium [6-8].

\footnotetext{
${ }^{a}$ Corresponding author: barani.k@lu.ac.ir
} 
Many studies were carried out on kaolinite flotation (pure samples) by cationic collectors such as ether diamine, hydroxyl-alkyl-diethanolamine, cetylpyridinium chloride, cetyltrimethylammonium bromide and dodecylamine. The results of these studies showed that kaolinite flotation by cationic collectors was better under acidic conditions than in alkaline media [7-13]. Yuehua et al. (2004) tried to increase kaolinite recovery in alkaline medium by using a macromolecule as a flocculant. Without polyacrylamide, the kaolinite recovery decreased from 70 to $15 \%$, with increasing the $\mathrm{pH}$ from 2 to 10. However, with polyacrylamide as a flocculant, kaolinite recovery increased under both acidic and alkaline conditions [11].

Comparison of flotation of kaolinite and quartz showed that two collectors (dodecylamine and EDA Flotigam) and two quaternary ammonium salts (cetylpyridinium chloride and cetyltrimethylammonium bromide) were the most effective collectors for floating both kaolinite and quartz. However, the time required for kaolinite flotation was 5-10 times longer that for the quartz flotation, depending on the type of collector [10].

The purpose of the present study is to investigate the recovery of kaolinite from tailings of kaolin washing plants using flotation and flotation-flocculation.

\section{Experimental}

\subsection{Materials}

Samples used in this study were taken from the tailing dam of the Zonouz kaolin washing plant in East Azerbaijan Province, Iran. The size distribution of the representative sample was carried out by laser diffraction (Fig. 1). It is observed that the percent passing 100 and $50 \mu \mathrm{m}$ is respectively $100 \%$ and $50 \%$, and more than $30 \%$ of the particles were smaller than $20 \mu \mathrm{m}$ (slime particles).

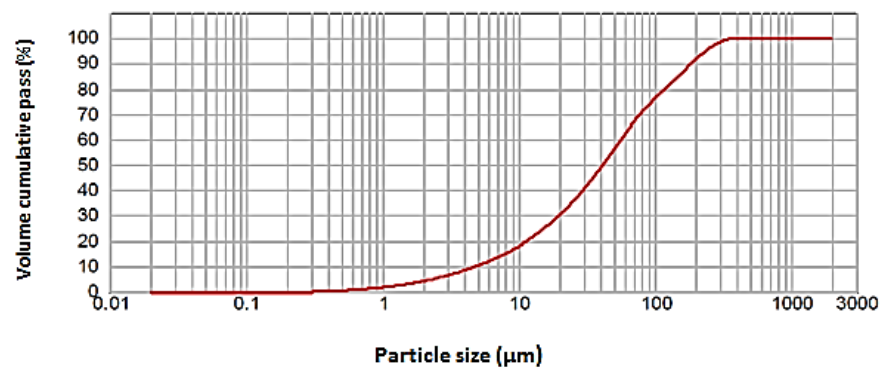

Figure 1. Particle size distribution of the tailing sample by laser diffraction.

According to the mineralogical analyses, it was found that the sample contained quartz, kaolinite and calcite as the main minerals, and muscovite, biotite, montmorillonite and iron-rich epidote as the minor minerals. The chemical composition of the sample is given in Table 1.

Table 1. Chemical composition of a sample.

\begin{tabular}{|c|c|c|c|c|c|}
\hline Composition & $\mathbf{S i O}_{\mathbf{2}}$ & $\mathbf{A l}_{\mathbf{2}} \mathbf{O}_{\mathbf{3}}$ & $\mathbf{K}_{\mathbf{2}} \mathbf{O}$ & $\mathbf{S O}_{\mathbf{3}}$ & $\mathbf{F e}_{\mathbf{2}} \mathbf{O}_{\mathbf{3}}$ \\
\hline $\mathbf{\%}$ & 74.67 & 15.35 & 0.25 & 0.11 & 0.33 \\
\hline Composition & $\mathrm{CaO}$ & $\mathrm{SrO}$ & $\mathrm{P}_{2} \mathrm{O}_{5}$ & $\mathrm{MgO}$ & L.O.I \\
\hline \% & 1.74 & $<0.01$ & $<0.01$ & $<0.01$ & 7.54 \\
\hline
\end{tabular}




\subsection{Flotation experiments}

Flotation experiments were carried out in a $1 \mathrm{dm}^{3}$ conventional laboratory cell (Denver model), at $25 \%$ solids ratio and agitation rate was $850 \mathrm{rpm}$. Pine oil was used as frother (150 g/ton), cetylpyridinium chloride (CPCI) and dodecylamine (DDA) as collectors, aluminum chloride as a depressant of quartz; sulfuric acid and sodium hydroxide as $\mathrm{pH}$ regulators. All reagents used in this study were of analytical grade.

The experiments were conducted in 5 parts. In each part, the effect of only one parameter was examined, while the other parameters were kept constant.

\section{Results and discussion}

\subsection{Effect of $\mathrm{pH}$ with $\mathrm{CPCl}$ as collector}

The first part of the experimental investigation was conducted to evaluate the effect of $\mathrm{pH}$ on the flotation results when CPCI was used as a collector. The results are illustrated in Fig 2. It can be seen, that with increasing $\mathrm{pH}$ from 3 to 9 the $\mathrm{Al}_{2} \mathrm{O}_{3}$ recovery decreased and $\mathrm{SiO}_{2}$ recovery increased. The assays of $\mathrm{Al}_{2} \mathrm{O}_{3}$ and $\mathrm{SiO}_{2}$ were respectively assumed as the kaolinite and quartz indicator recovery.

Figure 3 shows the structure of kaolinite crystal. At low $\mathrm{pH}(\mathrm{pH}<4)$ the layer to layer interaction between the alumina face surface $(00 \overline{1})$ and silica face surface $(001)$ was significant, as well as the interaction between the alumina face surface and edge surface (010). In this case, the cluster structures, and even more complex network structures, were formed by kaolinite particle aggregation. Figure 4 illustrates adsorption of cationic collector by the kaolinite cluster at low $\mathrm{pH}(\mathrm{pH}<4)$, forming a hydrophobic structure [13].

In alkaline medium, the interaction between the cationic collector and plane (001), which contained oxygen, was stronger than that of the plane $(00 \overline{1})$, which contained Al. The plane $(001)$ adsorbed hydrophobic collector, but the plane $(00 \overline{1})$ did not adsorb collector due to presence of $\mathrm{Al}$ and remained hydrophilic. As a results, collectors of the plane (001) were accumulated and formed structures which the outer surface was hydrophilic (Fig. 5) [9]. Therefore, as indicated in Fig. 2, kaolinite recovery decreased with increasing $\mathrm{pH}$. A pH of 3 was chosen as the optimum condition and was used in for further experiments.

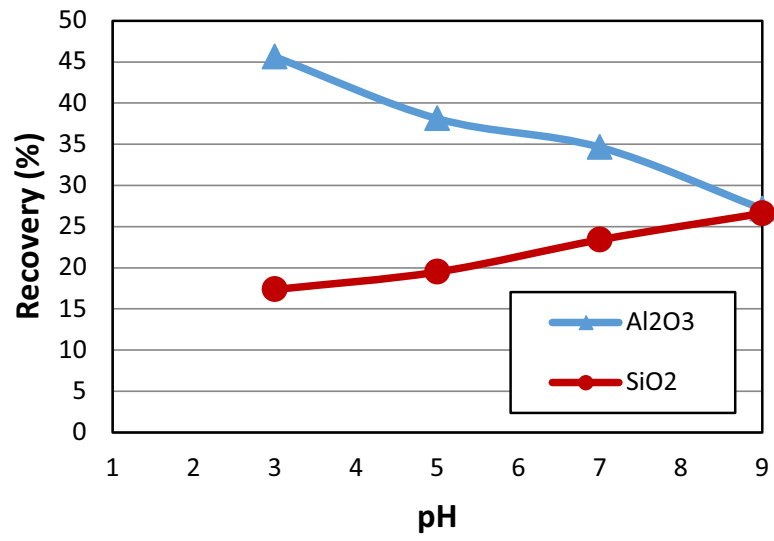

Figure 2. Flotation recovery of $\mathrm{Al}_{2} \mathrm{O}_{3}$ and $\mathrm{SiO}_{2}$ as a function of $\mathrm{pH}$ with $\mathrm{CPCI}$ as collector $(\mathrm{CPCI}=400 \mathrm{~g} / \mathrm{t}$, without depressant and de-slimming). 


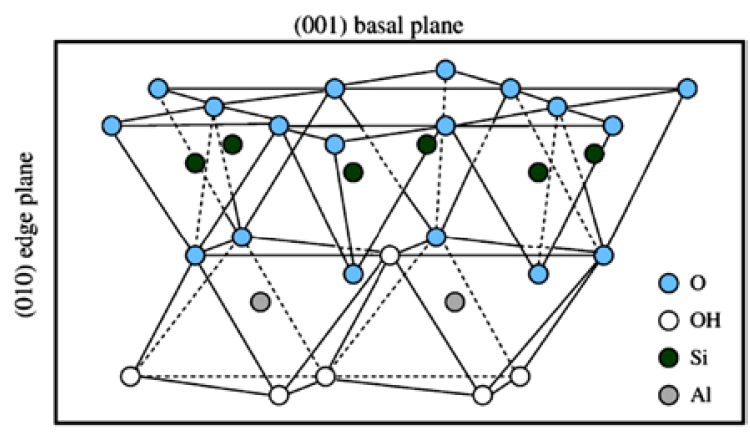

(00ī) basal plane

Figure 3. Structure of kaolinite [9].

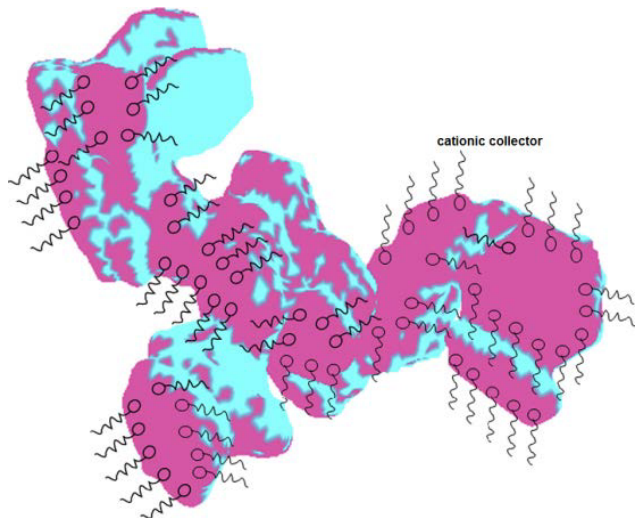

Figure 4. Kaolinite cluster adsorption of cationic collector at low pH. Pink surfaces represent the silica face surfaces of kaolinite particles and blue surfaces represent the alumina face surfaces of kaolinite particles [13].

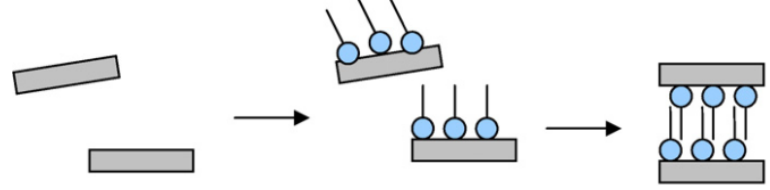

Figure 5. Schematic description of the kaolinite-amines interactions [9].

\subsection{Effect of concentration of $\mathrm{CPCl}$ collector}

The maximum recovery obtained for $\mathrm{Al}_{2} \mathrm{O}_{3}$ in the first part of investigation (section 3.1) was around $45 \%$, which was significantly low. For increasing the recovery of $\mathrm{Al}_{2} \mathrm{O}_{3}$, the effect of concentration of CPCI on the flotation results was investigated. Also the slime particles below $38 \mu \mathrm{m}$ were removed and aluminum chloride was presented used as the depressant.

The results in Figure 6 indicate that the $\mathrm{Al}_{2} \mathrm{O}_{3}$ recovery increased with increasing concentration of CPCI up to $600 \mathrm{~g} / \mathrm{t}$. The $\mathrm{Al}_{2} \mathrm{O}_{3}$ recovery at a $600 \mathrm{~g} / \mathrm{t}$ of CPCI exceeded $85 \%$. A further increased of $\mathrm{CPCI}$ concentration to $700 \mathrm{~g} / \mathrm{t}$, cause that the $\mathrm{Al}_{2} \mathrm{O}_{3}$ recovery was decreased to $81 \%$. It was probably due to occurrence of the critical because the critical micelle concentration phenomenon was occurring. Although, more research and evidence are needed to prove it. Also, it was observed that the $\mathrm{SiO}_{2}$ recovery was constant and equal to $20 \%$. It can be attributed to depression of quartz particles by aluminum chloride. The maximum separation efficiency (81\%) was achieved at $600 \mathrm{~g} / \mathrm{t}$ of CPCI. 


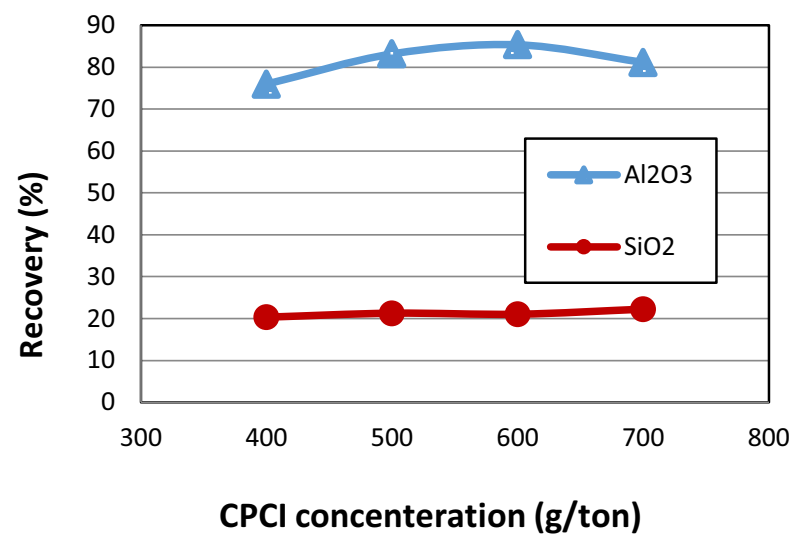

Figure 6. Flotation recovery of $\mathrm{Al}_{2} \mathrm{O}_{3}$ and $\mathrm{SiO}_{2}$ as a function of CPCI concentration ( $\mathrm{pH} 3$, aluminum chloride depressant $300 \mathrm{~g} / \mathrm{t}$, desliming $-38 \mu \mathrm{m})$.

\subsection{Effect of aluminum chloride concentration with $\mathrm{CPCl}$ collector}

The results of part 2 (section 3.2) showed that the $\mathrm{Al}_{2} \mathrm{O}_{3}$ recovery and separation efficiency were increased by using aluminum chloride as the quartz depressant. In this part, the effect and role of aluminum chloride was investigated. Figure 7 indicates that with increasing concentration of aluminum chloride from 300 to $600 \mathrm{~g} / \mathrm{t}$, the recoveries of $\mathrm{Al}_{2} \mathrm{O}_{3}$ and $\mathrm{SiO}_{2}$ did not significantly change. However, the best results were related to aluminum chloride value of $500 \mathrm{~g} / \mathrm{t}$, which produced the concentrate with recovery of $86.28 \% \mathrm{Al}_{2} \mathrm{O}_{3}$ and $20.19 \% \mathrm{SiO}_{2}$ and grade of $38.42 \% \mathrm{Al}_{2} \mathrm{O}_{3}$ and $52.96 \% \mathrm{SiO}_{2}$.

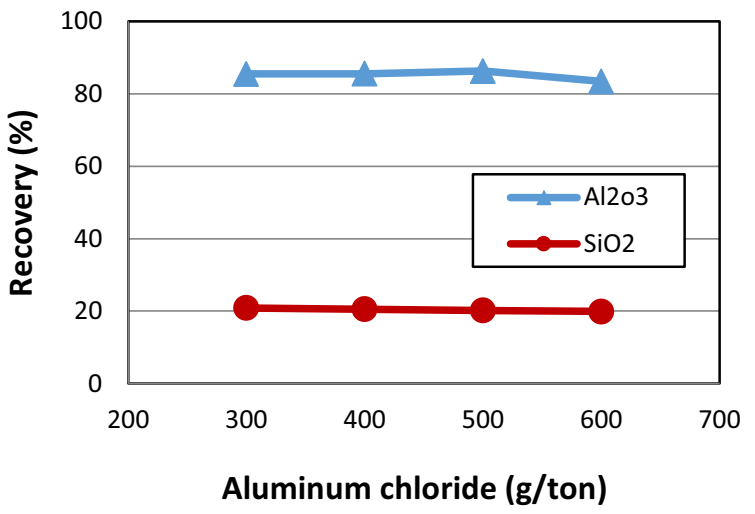

Figure 7. Flotation recovery of $\mathrm{Al}_{2} \mathrm{O}_{3}$ and $\mathrm{SiO}_{2}$ as a function of aluminum chloride concentration $(\mathrm{pH} 3, \mathrm{CPCI}$ $600 \mathrm{~g} / \mathrm{t}$, desliming $-38 \mu \mathrm{m})$.

Ions of aluminum chloride $\left(\mathrm{Al}^{+3}\right)$ play two positive roles during flotation. From one side they act as the depressant of quartz. In fact, these ions deposit on the surface of quartz, which has negative charge and competes with the collector ions that prevent quartz floatation. However, the excessive increased level of $\mathrm{Al}^{+3}$ increases the kaolin zeta potential. On the other side, these ions increase the ionic strength of the pulp. In a high ionic strength environment, although the negative charge on the 
basal the planes $(00 \overline{1})$ and $(001)$ is constant, the zeta potential caused by the surface charge on both basal planes and edges is significantly screened and thus aggregation of kaolinite particles can occur (Fig. 8). The surface charge at high ionic strength also weakens self-aggregation between the negatively charged $(00 \overline{1})$ planes and positively charged edge planes in the acidic pulp. Thus, the $\mathrm{pH}$ dependence of kaolinite flotation becomes less pronounced [9].

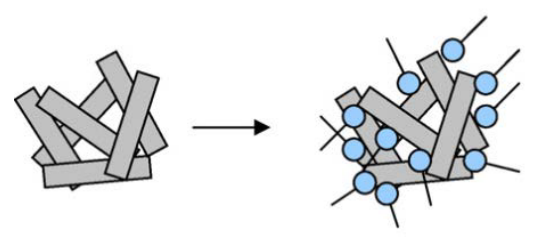

Figure 8. Aggregation of kaolinite particles in a high ionic strength environment [8].

\subsection{Effect of pH on with DDA collector}

Previous studies showed, dodecylamine (DDA) was the effective collector for flotation of both kaolinite and quartz [10]. In this part, flotation of kaolinite by DDA in the presence of aluminum chloride as quartz depressant was evaluated. Fig. 9 shows that during kaolinite floatation with DDA collector, with increasing $\mathrm{pH}$, both recoveries of $\mathrm{Al}_{2} \mathrm{O}_{3}$ and $\mathrm{SiO}_{2}$ increased. The maximum recovery of $\mathrm{Al}_{2} \mathrm{O}_{3}$ and $\mathrm{SiO}_{2}$ was obtained at $\mathrm{pH}=9$. It seems that, there are differences between the DDA and CPCI results. As it can be seen in Fig. 2, by using CPCI, with increasing pH, the $\mathrm{Al}_{2} \mathrm{O}_{3}$ recovery decreased. The effect of $\mathrm{pH}$ on selectivity separation is clearly shown in Figure 9. At $\mathrm{pH}=3$ the difference between $\mathrm{Al}_{2} \mathrm{O}_{3}$ and $\mathrm{SiO}_{2}$ recoveries was around $28 \%$ and a good selectivity was achieved. With increasing $\mathrm{pH}$ this difference was reduced and recoveries of $\mathrm{Al}_{2} \mathrm{O}_{3}$ and $\mathrm{SiO}_{2}$ were almost equal at $\mathrm{pH}=9$. The best results were obtain at $\mathrm{pH}=3$, where a concentrate with recovery of $66.25 \% \mathrm{Al}_{2} \mathrm{O}_{3}$ and $37.74 \% \mathrm{SiO}_{2}$, respectively, and assays of $20.84 \% \mathrm{Al}_{2} \mathrm{O}_{3}$ and $69.93 \% \mathrm{SiO}_{2}$.

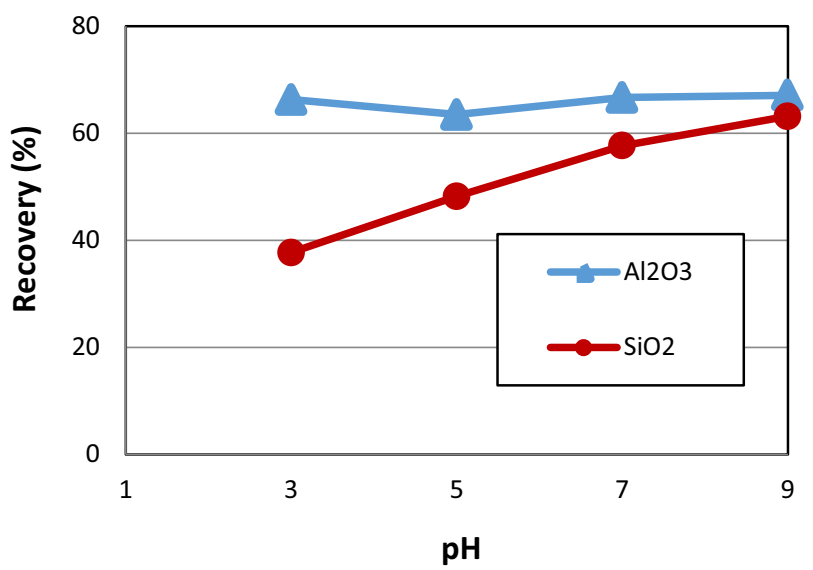

Figure 9. Flotation recovery of $\mathrm{Al}_{2} \mathrm{O}_{3}$ and $\mathrm{SiO}_{2}$ as a function of $\mathrm{pH}$ with DDA as a collector (DDA $600 \mathrm{~g} / \mathrm{t}$, aluminum chloride $300 \mathrm{~g} / \mathrm{t}$, desliming $-38 \mu \mathrm{m}$ ). 


\subsection{Effect of concentration of DDA collector}

The results of part 4 (section 3.4) showed that satisfactory separation of kaolinite and quartz by the DDA collector in the presence of aluminum chloride can be obtained in acidic pHs, but high dosage of the collector is required. In this part the effect of DDA concentration is studied.

Figure 10 indicates that the maximum recovery of $\mathrm{Al}_{2} \mathrm{O}_{3}$ at a concentration of $300 \mathrm{~g} / \mathrm{t}$ was equal to $80 \%$ but increasing DDA concentration decreased grade of $\mathrm{Al}_{2} \mathrm{O}_{3}$. Also, $\mathrm{SiO}_{2}$ recovery increased from 20 to $38 \%$ by increasing the DDA concentration. The best flotation results in term of grade and recovery of $\mathrm{Al}_{2} \mathrm{O}_{3}$ were achieved for collector concentration of $300 \mathrm{~g} / \mathrm{t}$. This condition, the concentrate with a grade of $36 \% \mathrm{Al}_{2} \mathrm{O}_{3}$ and $52 \% \mathrm{SiO}_{2}$ and recovery of $80 \% \mathrm{Al}_{2} \mathrm{O}_{3}$ and $21 \% \mathrm{SiO}_{2}$.

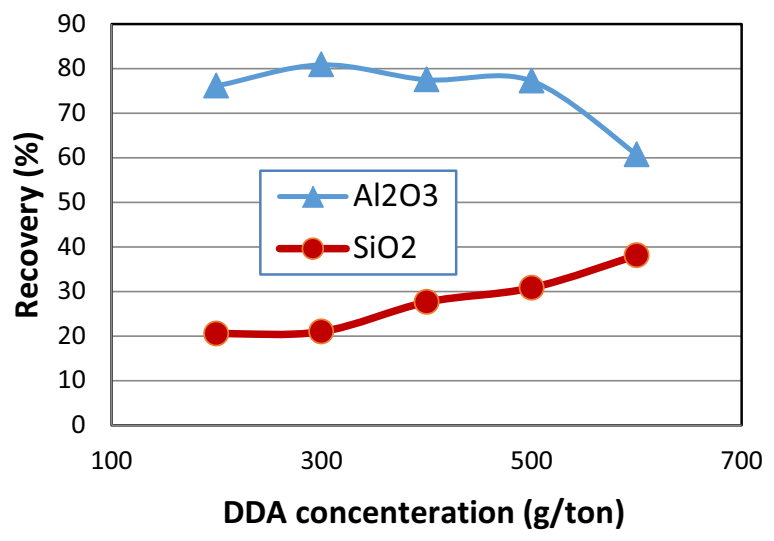

Figure 10. Flotation recovery of $\mathrm{Al}_{2} \mathrm{O}_{3}$ and $\mathrm{SiO}_{2}$ as a function of DDA concentration ( $\mathrm{pH} 3$, aluminum chloride $300 \mathrm{~g} / \mathrm{t}$, desliming $-20 \mu \mathrm{m})$

\section{Conclusions}

This paper showed that for both CPCI and DDA collectors, the best results were obtained at acidic $\mathrm{pH}$. It was shown that the best selectivity was obtained by using CPCI. Aluminum chloride had considerable effect on the floatation performance, which was an effective depressant for quartz. Flotation under acidic condition of $\mathrm{pH} 3$ caused problems such as equipment erosion at industrial scale.

\section{Acknowledgement}

The authors of this article would like to thank managers and engineers at Zonouz kaolin-washing plant for providing us with the samples, Lorestan University for providing the required equipment and chemical materials for the experiments and Iranian Mineral Processing Research Center (IMPRC) for performing chemical analysis.

\section{References}

1. H. H. Murray, Applied clay mineralogy: occurrences, processing and applications of kaolins, bentonites, palygorskitesepiolite, and common clays, vol. 2. (Elsevier, 2006)

2. M. Valaskova and G. S. Martynková, InTech (2012)

3. H. H. Murray, Int. J. Miner. Process., 7( 3), 263 (1980) 
4. R. J. Pruett, Min. Eng., 52(10), 21 (2000)

5. J. E. Kogel, SME (2002)

6. M. C. Fuerstenau, J. D. Miller, and M. C. Kuhn, Inc., New York, 132 (1985)

7. R. Koster, B. Schreck, W. von Rybinski, B. Dobiás, R. Kaster, B. Schreck, W. von Rybinski, and B. Dobias, Miner. Eng., 5(3), 445 (1992)

8. H. Jiang, Z. Sun, L. Xu, Y. Hu, K. Huang, and S. Zhu, Miner. Eng., 65, 124 (2014)

9. X. Ma, W. J. Bruckard, and R. Holmes, Int. J. Miner. Process., 93(1), 58 (2009)

10. O. M. S. Rodrigues, A. E. C. Peres, A. H. Martins, and C. A. Pereira, Miner. Eng., 40, 12 (2013)

11. H. Yuehua, S. Wei, L. Haipu, and Z. Xu, Miner. Eng., 17( 9-10), 1017 (2004)

12. C. Liu, Y. Hu, and X. Cao, Miner. Eng., 22(9-10), 849 (2009)

13. J. Liu, X. Wang, C. L. Lin, and J. D. Miller, Miner. Eng., 78, 58 (2015) 